\title{
脳虚血後神経細胞死のアポトーシス過程におけるカスペースの関与
}

\section{原英 彰}

\section{1. はじめに}

アポトーシス（apoptosis）は 1972 年に Kerr らにより 定義された細胞死の一形態である(1). アポトーシスの生 理的役割には 2 つあり，一つには発生過程や成熟個体にお いて余剩に用意された細胞や，十分に機能を果たした老化 した細胞などを除去することによって，生体の統制を測る 生体制御的な役割である。もう一つは生体にとって有害と なるがん細胞やウイルスに感染した細胞を排除する生体防 御的な役割である.アポトーシスが近年になり注目される ようになった要因の一つには, アポトーシスが様々な生理 学的過程あるいは病態に関係することがわかってきたこと にある．たとえば，アポトーシスの抑制がその病態と関わ ると考えられる疾患としては, 悪性腫瘍, 自己免疫疾患抒 よびウイルス感染症などがあり，一方アポトーシスの立進 が関わると考えられる疾患としては脳梗塞および心筋梗塞 などの虚血性疾患, エイズ, アルッハイマー病およびパー キンソン病などの神経変性疾患, アルコール性肝炎などが ある(2).アポトーシスの制御の乱れは，以上のような諸 種の病態と関連があることから，アポトーシスの分子機構 の解明ならびに薬物による制御は，これら疾患の治療や予 防につながることが考えられる，本稿では脳虚血神経細胞 死におけるアポトーシス過程に扔けるカスペース（caspase）の関与ならびにその制御による脳卒中の治療の可 能性, とくにカスペース阻害薬の有効性について紹介する.

\section{2. アポトーシスとネクローシス}

近年，アポトーシスの研究が進み，神経細胞死はネクロ ーシス（necrosis, 壊死）とアポトーシスに分類されるよ

キーワード:アポトーシス, カスペース, Bcl-2, 脳虚血, 神経細胞死, PARP

鐘紡株式会社薬品研究所薬効解析研究部

（ $5534-8666$ 大阪市都島区友渕町 1-5-90)

原稿受理日：1998 年 11 月 9 日
うになってきた。 ネクローシスは, 虚血, 毒物, 栄養不足, 高熱など各種の病理的要因により細胞が破壊された結果，

一群の細胞が起こす不慮の細胞死 (accidental cell death) である.この細胞死の形態学的変化は主に細胞質，とくに ミトコンドリアに顕著であり，オルガネラが壊れ，ATP 生産機能が失われ, 浸透圧制御機能を失って細胞の肥大, 融解を起こし, 細胞膜が破綻して細胞質が放出される．ま た炎症を伴うのが特徴である，一方，アポトーシスはプロ グラムされた細胞死 (programmed cell death) であり, 核内の構造変化を伴う細胞サイズの縮小から始まる. 細胞 や細胞内小器官の腫大はなく, 核にクロマチンの凝集 (clomatin condence) が認められ細胞表面の微䋐毛は消失し, 細胞の断片化に伴うアポトーシス小体 (apoptotic body) の形成が起こり, マクロファージや隣接する細胞によって 食食除去される.アポトーシスを検出する方法には, DNA 2 重鎖の断端を直接検出する terminal deoxynucleotidyl transferase-mediated dUTP-biotin nick-end labelling （TUNEL）法やアポトーシス特異的 DNA 断片化（クロマ チンDNAのヌクレオソーム単位の切断）を電気泳動法な どで検出する DNA 断片化検出（DNA laddering）法など がある.

脳神経細胞は虚血によって cell death signal を受ける と, 虚血の程度や虚血後の時間によってネクローシスある いはアポトーシスのいずれかの死に方をする．すなわちネ クローシスおよびアポトーシスともに一部において共通の シグナル伝達経路を有しており, その経路の分かれ目は細 胞内の ATP レベル, 細胞内 $\mathrm{Ca}^{2+}$ 濃度 $\left(\left[\mathrm{Ca}^{2+}\right]_{i}\right)$, ニュー ロンの成熟度, グルタミン酸受容体の種類およびグル夕ミ ン酸アゴニストの濃度等に依存して決定される $(3,4)$. 虚 血によって ATP の供給が長時間遮断されるとネクローシ スになるが，ある閾值以上に供給されていると ATPに依 存したアポトーシスのプロセスが遂行される（図 1).ア ポトーシスについてはさらに詳細な総説 $(2,5 \sim 8)$ がある ので参照して頂きたい. 


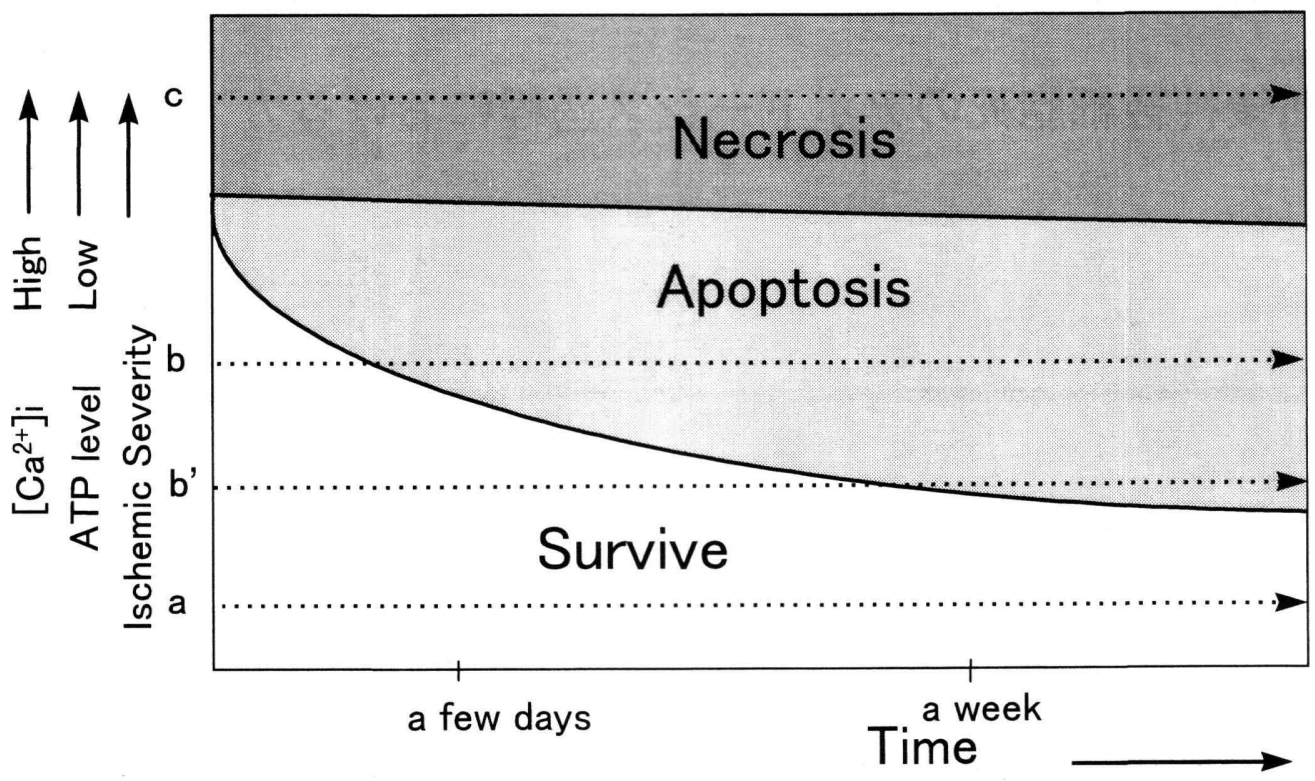

Fig. 1 Speculative mechanism of the cell death pathway between insult severity and time after ischemia. The resultant fate such as survival, apoptosis or necrosis may be dependent on insult severity and time after ischemia. a: non-ischemic region and cells that could protect themselves against the mild ischemia (Survive), b: penumbra region after moderate ischemia (Apoptosis). Apoptosis was shown in the region a few days after moderate ischemia. b': core region after mild ischemia (Apoptosis). In the case of mild ischemia, apoptosis was shown at a week after ischemia. c: ischemic core region after severe ischemia (Necrosis).

\section{3. 脳虚血とアポトーシス}

これまで脳虚血による細胞死はネクローシスと捉えられ てきた．しかし，虚血後の梗塞領域は壊死を起こしている が，梗塞巣の周辺領域に DNA 断片化が起きていることが TUNEL 法によって明らかになり, DNA laddering 法で 典型的な nucleosomal ladder が観察された $(9 \sim 13)$.さら に，虚血後の神経細胞死を RNA 合成およびタンパク合成 阻害薬（アニソマイシン，シクロヘキシミド）の投与で抑 制できるとの報告 $(14,15)$ もあることから, 脳虚血後の神 経細胞死にはネクローシスに加えてアポトーシスも一部関 与していることが考えられるようになった。 また, Kirino （16）によって見い出された一過性脳虚血後 2３日に見ら れる細胞死 (delayed neuronal death: 遅発性神経細胞死) の機序には，アポトーシスが関与していることが推察され ている $(17,18)$. しかし一方では, DNA 断片化は細胞死 の後に見られることから，アポトーシス以外の機序を想定 している報告もある(19).

ラット中大脳動脈閉塞モデルの再開通早期（2 時間閉塞 後再開通 1 2 日）に，虚血領域と非虚血領域との境界の 虚血領域内（ischemic penumbra,peri-infarct zone）にア ポトーシス細胞が認められ，これら細胞は虚血再開通後 30 分に出現して, 再開通後 1〜2 日にピークに達する (12). その後, 時間とともに減少して虚血 4 日後にはピーク時の 約 $1 / 4$ に低下し， 28 日後にはほぼ消失する. また前脳虚 血モデルにおいても虚血後 1〜2 日に DNA 断片化が認め られている $(9,11,20)$. 虚血の程度, $\left[\mathrm{Ca}^{2+}\right]_{i}$, 細胞内 ATP レベルおよび虚血後の時間に依存して細胞の運命は決定さ れ, 虚血後の細胞の運命としては生存, アポトーシスおよ びネクローシスの 3 タイプの分類が可能である（図 1). すなわち, (1)生存: ごく軽度の虚血の場合は, 細胞は死に 至ることなく生存する (図 1, a). 虚血による $\left[\mathrm{Ca}^{2+}\right]_{i}$ の 上昇, 細胞内 ATP レベルの低下がある間值（細胞死が認 められるか認められない境界）を越えない程度の虚血, た とえばマウスおよびラット中大脳動脈閉塞モデルでは 20 分以内の虚血, では組織学的に明らかな細胞死が認められ ない. (2)アポトーシス：中程度の虚血（たとえばマウスお よびラット中大脳動脈閉塞モデルでは 1〜2 時間虚血再灌 流）の後, ischemic penumbraにおいては虚血後 1〜2 日 から典型的なアポトーシス様細胞形態を示し, 約 1 週間以 
Table 1 Human caspase (ICE/CED3 protease) family

\begin{tabular}{|c|c|c|c|}
\hline Name & Other name & $\begin{array}{l}\text { Recognition } \\
\text { sequence }\end{array}$ & Protein substrates \\
\hline Caspase-1 & ICE & YVAD & pro-IL- $1 \beta$, pro-IL-18, pro-caspase 3 and 4 \\
\hline Caspase-2 & ICH-1, Nedd-2 & & PARP, pro-caspase 7 \\
\hline Caspase-3 & CPP32, Yama, apopain & DEVD & $\begin{array}{l}\text { PARP, DNA-PKcs, U1-70kD, hnRNP C1\& C2, } \\
\text { SREBPs, D4-GDI, PKC }{ }_{\delta}, \mathrm{I}_{\kappa} \mathrm{B}_{\alpha} \text {, huntingtin, fodrin, } \\
\text { pro-caspase } 6\end{array}$ \\
\hline Caspase-4 & TX, ICH-2, ICErel-II & & \\
\hline Caspase-5 & ICErel-III, TY & & \\
\hline Caspase- 6 & Mch2 & VEID & lamin $\mathrm{A} \& \mathrm{~B}$, pro-caspase 3 \\
\hline Caspase-7 & Mch3, ICE-LAP3, CMH-1 & & PARP, pro-caspase 6 \\
\hline Caspase-8 & MACH, FLICE, Mch5 & IETD & pro-caspase 3 \\
\hline Caspase-9 & ICE-LAP6, Mch6 & & PARP, pro-caspase 3 \\
\hline Caspase-10 & Mch4 & & pro-caspase 3 \\
\hline
\end{tabular}

The caspase family members can be divided into three subfamilies: caspase-1(ICE) subfamily (caspase-1, -4 and -5), caspase-2 (ICH-1) subfamily (caspase-2 and -9), and caspase-3 (CPP32) subfamily (caspase-3, -6, $-7,-8$, and -10 ). Modified from refs. 36 and 87.

内にはそれら細胞は死に至る（図 $1, \mathrm{~b})$ ．さらに軽度の虚 血においてもマウスおよびラットにおいて中大脳動脈によ って組織学的な細胞障害が認められる最小の時間である 30 分間虚血後再灌流では, アポトーシス細胞はさらに遅 れて出現する（図 1， b'）（21,22）。(3)ネクローシス：マウ スおよびラットの永久閉塞あるいは 3 時間虚血再灌流など の重度の虚血条件下では, 虚血早期から細胞内 ATP レベ ルが枯渇して虚血中心領域（ischemic core）においてア ポトーシスに陥ることなくネクローシスになる（図 1，c）。 虚血とアポトーシスに関してはいくつかの総説 $(23 \sim 25)$ がある.

\section{4. カスペースファミリー}

線虫 (Caenorhabditis elegans) の遺伝子学的解析から 細胞死を抑制する遺伝子と ced-9 が，ヒトの前がん遺伝子 の Bcl-2 と構造的・機能的に相同であること (26), さらに すべての細胞死に必須の遺伝子 ced-3が，ヒトのカスペー ス (caspase) -1 (interleukin-1 $\beta$ converting enzyme: ICE)
と相同なタンパク質をコードすることが明らかにされた (27). カスペースファミリーは哺乳類の場合, 今までに少 なくとも 10 種類の遺伝子がクローニングされている（表 1).いずれも活性中心にQACRG のアミノ酸配列を有す るシステインプロテアーゼで, その構造の類似性から ICE 様 (カスペース 1,4,5), CPP32 様(カスペース 3, 6, 7, 8, 10) および ICH-1 様（カスペース 2,9）に大別される. cDNA の構造およびタンパク質結晶構造の解析から, ヒトカスペ 一ス 1 は 404 のアミノ酸（p45）からなり, 活性化により 大サブユニット（p20）と小サブユニット（p10）の接合 部の Asp-X（X は任意のアミノ酸）のところで切断（タン

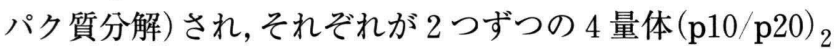
を作って機能することが明らかになった $(28,29)$.

カスペースは通常不活性の状態で存在しており, アポト ーシスの信号を受け取った時にのみ活性化される. カスペ ースファミリーの活性化はアポトーシスのカスケードを開 始させ細胞死を誘導すること，カスペース 1 を欠損したマ ウスではアポトーシスの一部が抑制されること $(30 〜 32)$, 


\section{Contralateral Ipsilateral}

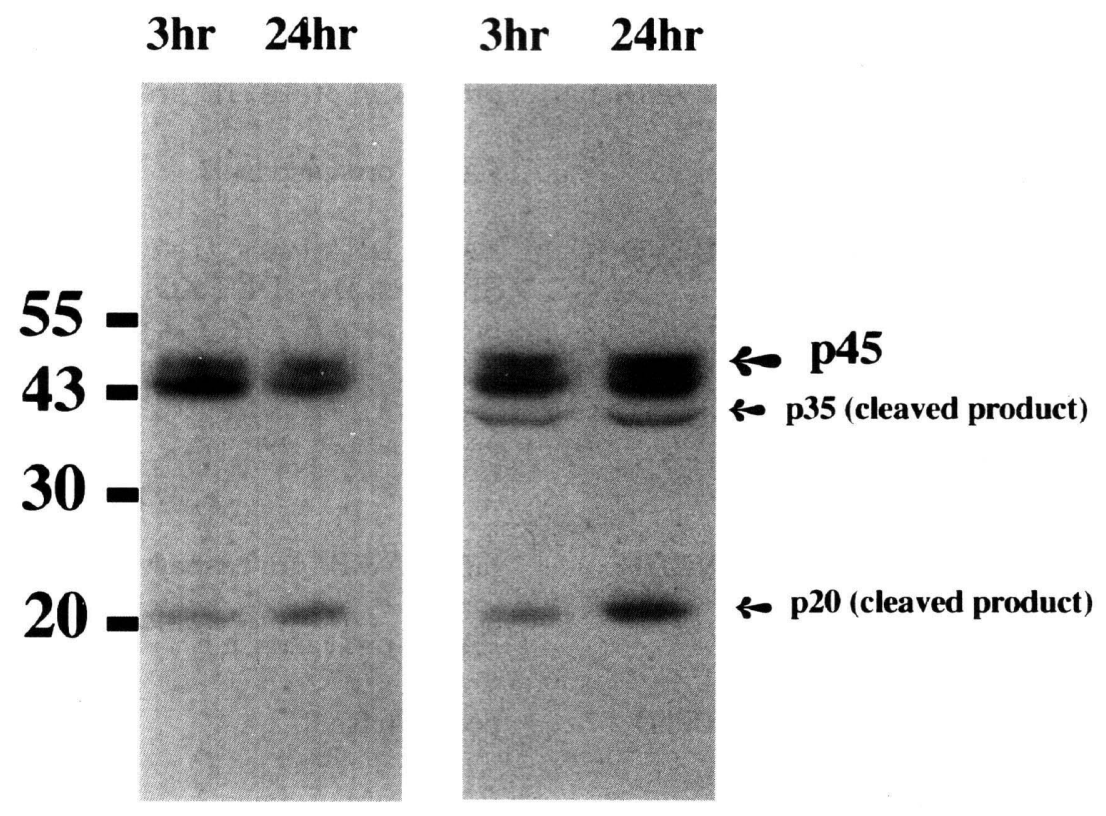

Fig. 2 Caspase-1-like protease expression in mouse brain after left MCA filament occlusion and reperfusion. Immunoreactive cleaved products p35 and p20 increased in the ipsilateral hemisphere at $3 \mathrm{hr}$ and $24 \mathrm{hr}$ of reperfusion, respectively, after $3 \mathrm{hr}$ of MCA occlusion. There was no significant difference between normal brain (sham) and the nonischemic contralateral hemisphere (data not shown).

またカスペースファミリーの活性を阻害するウイルス由来 の CrmA（32）やp35（33）などのタンパク質やペプチド 誘導体のカスペース阻害薬が細胞死を抑制すること(34) などから，カスペースファミリーがアポトーシスに深く関 与していることが明らかになってきた $(28,29,35,36)$.

\section{（1）虚血後のカスペースの変化}

ラット中大脳動脈永久結紮による局所脳虚血モデルにお いて，カスペース 2 (Nedd-2) およびカスペース 3 (Yama CPP32）mRNA は虚血後 8～24 時間に虚血側の大脳半球 で発現したが，カスペース 1 には明らかな変化が認められ なかった (37). マウス局所脳虚血モデルにおいては，3 時 間虚血 3 時間および 24 時間再開通後に活性化されたカス ペース 1 にみらる p20の発現が上昇し(38）（図 2)，2 時間虚血再開通 1 時間後に虚血側大脳半球でカスペース 3 様酵素活性の上昇が観察され，12２4 時間後に虚血領域 内の同一神経細胞内にカスペース 3 の活性体と考えられる p20 の免疫染色と TUNEL 染色の共存が確認された (39). さらにラット前脳虚血モデルにおいても 15 分間虚血再開 通後 8〜 72 時間にカスペース $3 \mathrm{mRNA} レ$ レルの上昇が虚
血領域である海馬 CA1 領域および線条体において認めら れた(40). Ni ら (41) および Gillardon ら (42) も同様な 成績を得ている。一方, スナネズミ一過性前脳虚血モデル においては 10 分虚血再開通後 $3 \sim 6$ 時間に虚血領域でカス ペース 2 mRNA レベルが上昇するが，カスペース 1 , カ スペース 3 およびカスペース 4 (TX/ICErel-II) のレベル は 48 時間以内では明らかな変化は示さなかった(43)。し かし, カスペース 1 様の mRNA が 72 時間後には CA1 領 域に発現してくるとの報告もある(44). また, Bhat ら (45) はスナネズミ一過性前脳虚血モデルにおいてカスペース 1 mRNA のレベルが虚血後 4 日に海馬 CA1 領域のマイク ログリアで上昇したことより，カスペース 1 はアポトーシ スよりも炎症過程の活性化に関与している可能性を示唆し ている.

Fluid-percussion 法を用いた外傷性のラット脳損傷モデ ルにおいても損傷後 24 時間にカスペース 1 およびカスペ ース 3 mRNA が上昇した(46). さらに, バルーンカテー テルを用いたウサギ脊髄虚血モデルにおいても，カスペー ス 1 , カスペース 2 拈よびカスペース 3 の発現が 15 分間 

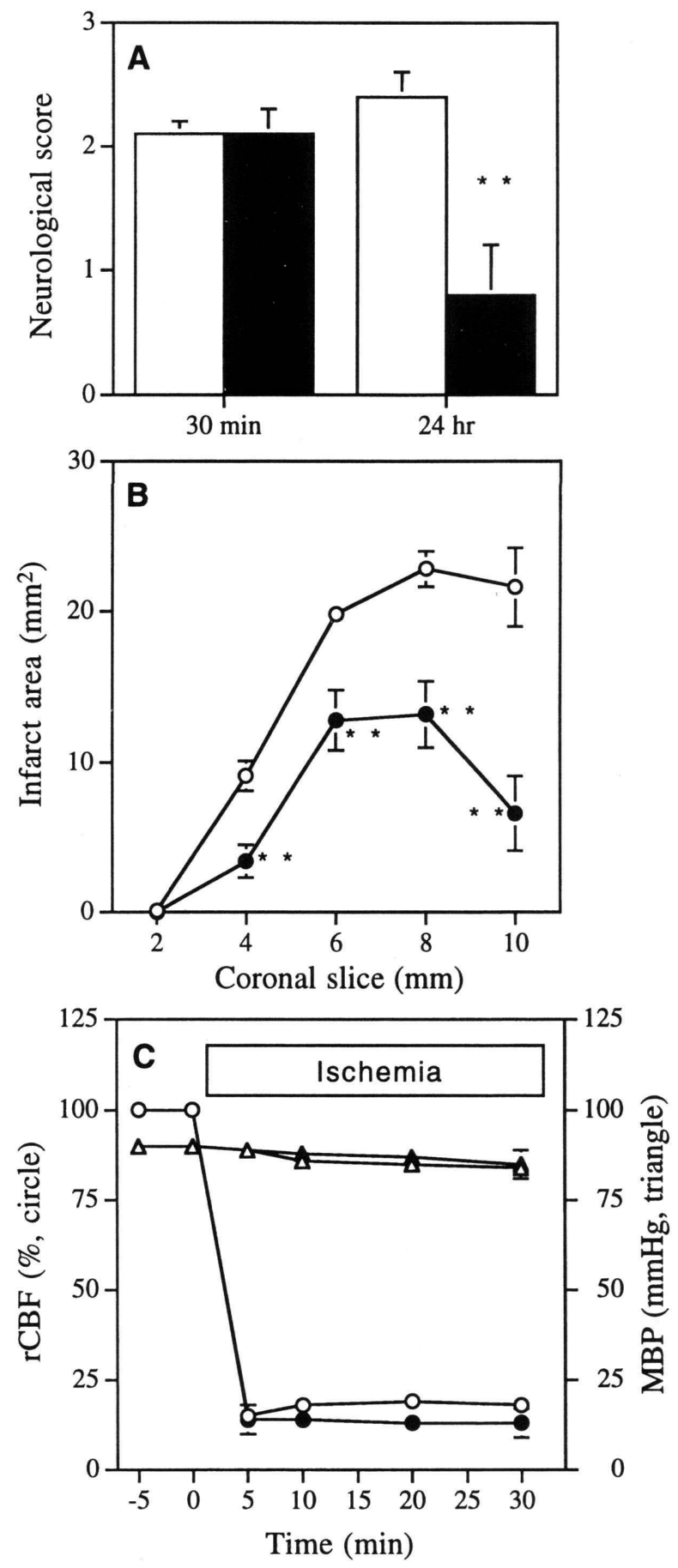

虚血再開通後 8 時間に上昇し， 2 日後にはもとのレベルに ほほ回復した $(47)$.

以上，動物種や虚血モデルによってそのカスペースファ ミリーのメンバーの挙動は若干異なっているものの, 虚血 によって虚血領域あるいは虚血周辺領域にカスペースの活 性が上昇することが明らかになった。

(2) 各種カスペーストランスジェニックマウスに関

\section{する研究}

内因性カスペース 1 をドミナントネガティブに阻害する と考えられるミュータントカスペース 1 タンパク質を発現 したトランスジェニックマウス (48) を用いて, 中大脳動 脈を 3 時間閉塞して 24 時間再開通させた時（虚血再開通 モデル）の脳細胞障害の程度を脳梗塞および神経症状を指 標にして検討した. 同マウスの脳虚血再開通後の脳梗塞巣 は, 野生型マウス（コントロール）と比較して有意に縮小 し, 虚血後に認められる片麻痺, 回転運動などの神経症状 および DNA 断片化の発現なども抑制された(49). 24 時 間虚血後（永久閉塞モデル）においても同様に神経症状の 改善および脳梗塞巣の縮小が認められた（図 3）（48）。近 年, カスペース 1 ノックアウトマウスにおいても同様に脳 虚血後の細胞障害が軽減されることが確認された $(50)$.

カスペース 2 ノックアウトマウスの虚血 24 時間後の脳 梗塞巣および神経症状は, 野生型マウスと比較して明らか な差が認められなかったことから (51), 脳虚血後神経細胞 障害の機序にカスペース 2 の関与は少ないことが考えられ る. カスペース 2 ノックアウトマウスは正常に発育するが, 生殖細胞が卵巣に過㮃に作られることから, 発生過程のア ポトーシスに影響を及ぼしている可能性が示唆されている (51).

カスペース 3 ノックアウトマウスを用いて脳虚血実験を 検討した報告は現在のところ見当たらない。このマウスは $2 / 3$ が胎仔で死亡し, 出生したマウスにおいては脳, とく に大脳皮質核と海馬の細胞数の増加とアポトーシスの異常 がみられ，3 週間以内にすべてのマウスが死亡し，中枢神 経系の発生過程におけるアポトーシスが抑制されていた. しかし，その他の臟器に関しては明らかな異常は認められ ていない $(90)$ ここのことはカスペース 3 が脳神経系の発生

Fig. 3 Protection from MCA occlusion-mediated infarct in ICE transgenic mice compared to wild-type mice. A: Neurological grading $30 \mathrm{~min}$ and $24 \mathrm{hr}$ after occlusion. Neurological grading: 0, no neurological deficits; 1 , failure to extend the right forepaw; 2, circling to the contralateral side; 3 , loss of walking reflex. Open column: wild-type mice, closed column: transgenic mice, B: Infarct area assessed at $24 \mathrm{hr}$. $\bigcirc$ : wild-type mice, 0 : transgenic mice, C: Regional cerebral blood flow ( $\mathrm{rCBF}, \bigcirc$ : wild-type mice, $\mathrm{O}$ : transgenic mice) and mean blood pressure (MBP, $\triangle$ : wild-type mice, $\mathbf{\Delta}$ : transgenic mice) during $30 \mathrm{~min}$ of ischemia. Data are represented as means \pm S.E. (Standard Error of the Mean) $(\mathrm{n}=11$ or 14$) .{ }^{* *}: \mathrm{P}<0.01$ vs. Vehicle (Dunnett's test). Reproduced with permission from ref. 48. 
Table 2 Caspase inhibitors

\begin{tabular}{|c|c|}
\hline Caspases & Inhibitors \\
\hline ICE family & ZVAD-FMK $^{\mathrm{a}, \mathrm{b}, \mathrm{e}, \mathrm{e}}, \mathrm{ZD}^{-\mathrm{DCB}^{\mathrm{b}, \mathrm{e}}}, \mathrm{CrmA}$ (cowpox virus), p35 \\
\hline Caspase-1 & $\mathrm{YVAD}^{\left.-\mathrm{CMK}^{\mathrm{a}, \mathrm{b}, \mathrm{d}, \mathrm{d}, \mathrm{e}}\right)}$ (competitive irreversible), YVAD-CHO ${ }^{\mathrm{c}, \mathrm{d}, \mathrm{e})}$ (competitive reversible) \\
\hline Caspase-3 & ZDEVD-FMK ${ }^{\mathrm{a}, \mathrm{c}, \mathrm{e}}$, DEVD-CHO ${ }^{\mathrm{e}}$ \\
\hline Caspase-6 & VEID-FMK ${ }^{\mathrm{b})}$ \\
\hline Caspase-8 & IETD-FMK ${ }^{\mathrm{b})}$ \\
\hline
\end{tabular}

zFA-FMK $^{\text {a) }}$ (Z-Phe-Ala-FMK, a cathepsin B inhibitor) is used as a negative control (refs. 38 and 88). ${ }^{\text {a) }}$ Enzyme System Products, ${ }^{\mathrm{b})}$ Peptide Research Center, ${ }^{\mathrm{c}}$ Cosmo Bio, ${ }^{\mathrm{d})}$ Wako, ${ }^{\mathrm{e})}$ Takara Biomedicals

過程における細胞死の誘導に重要な役割を果たしているこ とを示唆している. 一方, カスペース 1 トランスジェニッ クマウスは発生過程において何ら変化が認められなかった ことから $(30,31,48)$, カスペース 1 はマウスの発生・器官 形成過程のアポトーシスの遂行には必須ではないのかもし れない.

\section{（3）虚血後神経細胞障害に及ぼすカスペース阻害薬 の影響}

脳虚血後の神経細胞障害の機序を解明する最も有効な手 段は，それぞれのカスペースに選択性の高い阻害薬を用い て脳虚血後の神経細胞障害に対する作用を検討することで ある. カスペースが活性化される際に切断される部位の配 列をもとにデザインされた合成ペプチド阻害薬は，それぞ れある程度の特異性を持ってプロテアーゼ活性を阻害する (表 2).ZVAD-FMK はカスペースを非選択的に阻害する カスペース阻害薬である. YVAD-CHO はカスペース $3(\mathrm{Ki}$ $=12 \mu \mathrm{mol})$ よりもカスペース $1(\mathrm{Ki} \leq 1 \mathrm{nmol})$ に対して 1 万倍以上選択性があり, IL-1 $\beta$ の 2 番目のプロセッシン グ部位における $\mathrm{P} 1 \sim \mathrm{P} 4$ 配列に対応する YVAD をベース にデザインされている. DEVD-CHO はカスペース 3 の基 質である poly（ADP-ribose） polymerase (PARP) の切 断部位に相当するDEVDをもとにして作られており，力 スペース 1 に対しても弱い阻害作用を有するがカスペース $3(\mathrm{Ki}<1 \mathrm{nM})$ に対して選択的で強い阻害作用を有してい る(28)。このようにYVAD および DEVDは，それぞれ主 としてカスペース 1 およびカスペース 3 の阻害薬として利 用できる．またカスペース 6 およびカスペース 8 の阻害薬 として，それぞれ YEID およびIETDがある。これらテ トラペプチドにアルデヒド基 (-CHO), クロロメチルケ
トン基（-CMK）およびフルオロメチルケトン基（-FMK） などを付けた合成ぺプチド阻害薬は国内外の各試薬メーカ 一 (ペプチド研究所, 大阪; 和光純薬工業 (株), 大阪 ; コスモバイオ, 東京; 医学生物学研究所, 名古屋; Enzyme System Products, Dublin, CA, USA ; 宝酒造, 東京) か ら購入できる (表 2).

(1)ZVAD の効果

非選択的かつ非可逆的なカスペース阻害薬である ZVAD-DCB およびZVAD-FMKの脳室内投与は，それぞ れラットおよびマウスの中大脳動脈閉塞後の脳梗塞巣を減 少させた $(38,52)$. ZVAD-FMK（虚血 15 分前および虚血 再開通直後の 2 回脳室内投与）はマウス 2 時間虚血再開通 直後から認められる片麻疩, 回転運動などの神経症状に対 しては明らかな作用を示さなかったが，再開通 18 時間後 の神経症状を改善した（図 4）（38）。また ZVAD-FMKは 虚血後 18 時間に認められる非活性型酵素の $\mathrm{p} 45$ から, 酵 素分解を受けて活性化されて生じる産物（p35 および p20） の産生を抑制した.このことはZZVAD-FMK 投与によっ て虚血後のカスペースの活性化が抑制されたことを示唆し ている．また，ZVAD-FMK は虚血前または虚血再開通直 後の単回投与においても梗塞巣ならびに神経症状に対して 効果を示したが, 虚血再開通後 1 時間投与ではその作用は 明らかではなかったことより (38), ZVAD-FMK の有効性 は投与後 1 時間以内であった. 一方，ネガティブコントロ ールとして用いたカテプシン B 阻害薬 ZFA-FMK $(53,54)$ は何ら作用を示さなかった (38).

マウス線条体内への $\alpha$-amino-3-hydroxy-5-methyl-4isoxazole propionate (AMPA) あるいは $N$-methyl-Daspartate（NMDA）の微量注入により誘発される神経細 

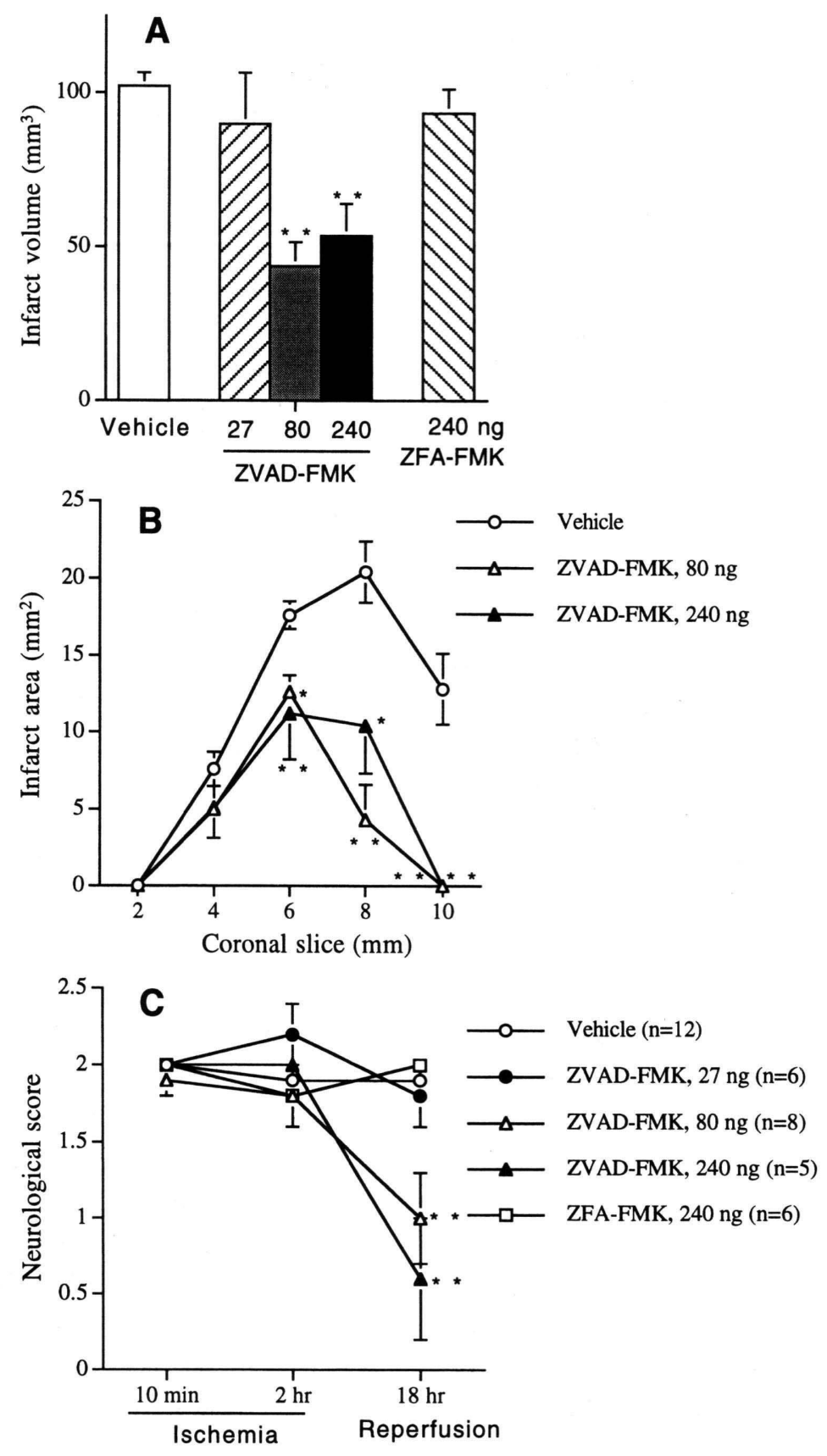

Fig. 4 Effects of ZVAD-FMK and cathepsin B inhibitor (ZFA-FMK) on infarct volume (A) and area (B) and neurological deficits (C) after transient focal ischemia in SV-129 mice. Animals were subjected to MCA filament occlusion for $2 \mathrm{hr}$ and reperfused for $18 \mathrm{hr}$. Vehicle (O), ZVAD-FMK [27 ng/body as a total dose (13.5 $\mathrm{ng} / \mathrm{body}$, twice), ], ZVAD-FMK ( $80 \mathrm{ng}, \triangle$ ), ZVAD-FMK (240 ng, $\mathbf{\Delta}$ ) and ZFA-FMK (240 ng, $\square$ ) were injected i.c.v. 15 min before ischemia and immediately after reperfusion. Drugs were dissolved in 0.2 to $0.6 \%$ dimethylsulfoxide (prepared with 0.1 M PBS, pH 7.4) and injected twice ( $2 \mu \mathrm{ml}$ per dose). Infarct area was determined in each of five coronal sections $(2 \mathrm{~mm})$ from anterior $(2 \mathrm{~mm}$ from anterior pole) to posterior $(10 \mathrm{~mm}$; B). ZVAD-FMK (80 and $240 \mathrm{ng}$ ) decreased the infarct volume and neurological deficits, whereas ZFA-FMK (240 ng) did not. After treatment with ZFA-FMK and ZVAD-FMK, infarct areas did not differ from the vehicle treated mice in the 5 coronal sections (data not shown). Data are presented as means \pm S.E. $(\mathbf{n}=5-12) .{ }^{*}: \mathrm{P}<0.05,{ }^{* *}: \mathrm{P}<0.01$ vs. Vehicle (Dunnett's test). Reproduced with permission from ref. 38. 
胞障害に対して, ZVAD-FMK（24 ng）はこれら興奮性ア ミノ酸との同時線条体内投与によって AMPA 誘発神経細 胞障害を抑制したが，NMDA 誘発神経細胞障害に対して は明らかな作用を示さなかった (38)。 しかしょり高濃度の ZVAD-FMK $(80 \mathrm{ng})$ を脳室内へ投与することによって NMDA 誘発神経細胞障害は抑制された. 両興奮性アミノ 酸の投与量は線条体内注入によってほほ同じ障害領域（体 積）を示すように設定した，以上，ZVAD-FMK は低濃度 でAMPA 誘発神経細胞障害を抑制し, 高濃度でNMDA 誘発神経細胞障害を抑制したことから，アポトーシスには NMDA 受容体よりもAMPA 受容体を介した機序の方が より密接に関与しているのかもしれない. 今後さらなる検 討が必要であろう。

(2)YVAD およびZDEVD の効果

カスペース 1 に選択的な阻害薬 YVAD-CMKも ZVADFMK と同様にマウス中大脳動脈閉塞再開通後の脳梗塞巣 の抑制および神経症状の改善が認められた (38). またカス ペース 3 に選択的な阻害薬 ZDEVD-FMK も ZVAD-FMK やYVAD-CMK よりも約 4 倍弱いが同様な作用が認めら れた. ラット前脳虚血モデルにおいてもZDEVD-FMKの 脳室内投与によって, 海馬でのカスペース 3 の活性化が抑 制され，CA1 領域における細胞死ならびに DNA 断片化も 抑制された(40).

マウス中大脳動脈閉塞再開通後 30 分をピークに上昇す る IL-1 $\beta$ は，ZVAD-FMK の脳室内投与によって抑制され たが，ZDEVD-FMKの投与によっては何ら変化しなかっ た(38). また, 虚血後の IL-1 $\beta$ の上昇はカスペース 1 卜 ランスジェニックマウスにおいて野生型マウスと比較して 抑制されることや(49), IL-1 受容体拮抗薬も虚血後の脳 梗塞を抑制することが報告されている $(55,56)$. IL-1 $\beta$ は 炎症反応を伝達する代表的なサイトカインの一つであり， IL-1 $\beta$ が上昇することは炎症反応が活性化されたことを示 している. 以上，ZVAD-FMK およびYVAD-FMK 投与に よる，あるいはカスペース 1 トランスジェニックマウスに おける脳虚血後神経細胞障害に対する抑制作用には, 虚血 後のアポトーシス立進の抑制のみならず局所的な抗炎症作 用も一部関与していることが考えられる.したがって, ZDEVD-FMK による抑制作用は，抗炎症作用に基づくも のではなく虚血後のアポトーシスの充進を抑制した可能性 が考えられる. すなわち虚血後のアポトーシスの立進のよ り選択的な抑制にはカスペース 1 よりもカスペース 3 の阻 害の方が適していることが推察される. しかしこれらの点 についてはカスペース 1 およびカスペース 3 以外のカスペ 一スの関与, たとえばカスペース 8 , カスペース 9 あるい はカスペース 11 などについても今後の検討が必要であろ う.

\section{(4) Poly (ADP-ribose) polymerase (PARP) の関与}

PARP は損傷を受けた DNA 修復に作用すると考えられ ており, 活性化されたカスペース 3 の基質でありカスペー ス 3 により限定分解される. 最近ではカスペース 2 , カス ペース 7 およびカスペース 9 も PARPを分解することが 明らかになっているが, 分解されることによってアポトー シスが進行することの直接的な証拠はまだ得られていない. PARPの非選択的な阻害薬 3-aminobenzamide（3-AB） の投与はマウス局所脳虚血後の細胞障害を抑制し (57), ま た，虚血後の神経細胞障害はPARPノックアウトマウス において野生型マウスと比較して軽減された $(57,58)$.さ らに, 虚血後に poly（ADP-ribose）が上昇することも確 認された(57). しかし, PARPノックアウトマウスと野生 型マウスの間には TUNEL 陽性細胞数および DNA ladderingにおいて明らかな差は認められなかった(57). そ の機序の詳細は不明であるが, DNA 断片化にはPARP の 分解は必要としないこと (59), PARPノックアウトマウス においては発達過程のアポトーシスが影響されないこと (60)，あるいはカスペース 3 は PARP 以外の基質を分解 して虚血によるアポトーシスの信号を伝達していること等 の可能性が考えられる.

\section{Bcl-2 ファミリー}

\section{（1）アポトーシスにおける Bcl-2 ファミリーの役割}

Bcl-2 は 1984 年 Tsujimoto らによりヒト滤胞性リンパ 腫にみられるがん遺伝子として発見された(61). Bcl-2 は キナーゼ，転写因子, 増殖因子や $\mathrm{G}$ タンパク質のような 従来のがん遺伝子産物とは異なり, その過㮃発現によりア ポトーシスを抑制することが明らかになった. さらに BclXL，Bcl-w，Bfl-1 および Brag-1 もアポトーシスを阻害す るタンパク質である. 一方, Bax, Bad, Bak, Bil, Bcl-XS, Bid および Hrk はアポトーシス誘導に働くタンパク質で ある.このように同じファミリー内に細胞死を防止する夕 ンパク質と促進するタンパク質が共存していることは興味 深い.

アポトーシスを抑制する Bcl-2 発現は, カスペースの活 性化に導くステップを抑制する $(3,62)$. アポトーシスのシ グナルが細胞に入るとミトコンドリアの膜電位が低下する. この膜電位の低下は膜透過性の増大を引き起こし, ミトコ ンドリア内のアポトーシスシグナル伝達物質であるチトク ロム c (63〜65) や AIF (apoptosis-inducing factor) （66） などが細胞質内へ流出する。この AIF は単離核に対する アポトーシス誘導能とカスペースファミリーの活性化能を 有して抢り，またチトクロム $\mathrm{c}$ はカスペースファミリーの 活性化能を有しておりアポトーシスを誘導する. Bcl-2や 
Bcl-XL はミトコンドリアや小胞体膜に局在するが，ミト コンドリアでは膜電位の低下の抑制ならびにチトクロム $\mathrm{c}$ や AIF などの放出を抑制することにより，カスペースフ アミリーの活性化を抑制するとされている(67).

以上, Bcl-2 ファミリーによる細胞死の制御はファミリ 一内の仲間同士の複雑で特異的な相互作用であり, 主とし てミトコンドリアの膜で起こることが次第に明らかになっ てきた (68).

\section{(2) 脳虚血後の Bcl-2 ファミリーの変化}

ラット中大脳動脈閉塞後 1 2 時間に虚血周辺領域にお いて Bcl-2 タンパク質が誘導された(69)。またラット 4 血 管閉塞前脳虚血モデルにおいて, Bcl-2 および Bcl-XL mRNA が虚血後 72 時間以降に細胞死が認められる領域 (CA1 領域) および細胞死が認められない領域（CA3 領域 および歯状回の分子層）において虚血再開通後 24 時間を ピークに発現し， 72 時間後には消失した. しかし，Bcl-2 および Bcl-x タンパク質は CA3 領域および歯状回にのみ 発現していた. Bcl-2 および Bcl-xL mRNA は生存細胞お よび死細胞の両方に認められたが，それらタンパク質は死 細胞のみに発現していた (70). Bax mRNA は CA1 領域に おいて虚血後 24 時間をピークに虚血後 8 時間から 72 時間 まで, CA3 領域および歯状回においては虚血後 24 時間の みに発現し，Bax タンパク質は CA1 領域および歯状回に 発現していた (71). スナネズミ一過性脳虚血モデルにおい て虚血後 24 時間に Bcl-2 および Bcl-x mRNA のレベルが 増加するが, Bax mRNAのレベルは変化しなかった (44). 一方, Bcl-2 および Bcl-x mRNA はラット局所脳虚血モデ ルにおいて何ら変化しないとする報告もある(37). 以上， アポトーシスを抑制するタンパク質 (Bcl-2 および Bcl-x) と促進するタンパク質（Bax）は虚血後の変化に明らかな 違いがないこと，また虚血モデルにおいて Bcl-2 および Bcl-x mRNAの変化に違いがあることなどから, 現時点 において脳虚血後の神経細胞障害の機序における Bcl-2 フ アミリーメンバーそれぞれの役割はまだ十分に明らかにさ れていない.

Bcl-2 を過剩発現したマウスにおける中大脳動脈閉塞後 の脳梗塞巣は, 野生型マウスと比較して軽減された (72). またラット局所脳虚血障害およびラット海馬培養神経細胞 における酸素ラジカル誘発薬（アドリアマイシン），グル 夕ミン酸あるいは低血糖による神経細胞障害に対して Bcl-2 を発現させた herpes simplex virus（HSV）ベクタ 一は抑制作用を示した $(73 〜 75)$ 。このことは Bcl-2 を活性 化させることによって神経細胞死を制御できることを示唆 している.

\section{6. p53}

p53 はヒトでは 17 番染色体短腕上に存在し, 393 個の アミノ酸からなる DNA 結合タンパク質をコードしており, 細胞死の誘導に関連しているがん抑制遺伝子である (76). p53 ノックアウトマウスにおけるカイニン酸（皮下投与) による海馬神経細胞障害 $(77)$ および脳虚血後神経細胞障 害は, 野生型マウスと比べて軽減される $(23,24,78)$. 一方, 培養大脳皮質および海馬神経細胞における p53 の過剩発 現はアポトーシスを誘導した $(79,80)$.このように, 脳虚 血後神経細胞障害の機序の一部に p53 が関与しているこ とが明らかになってきた.

\section{CAD 阻害薬}

細胞死の細胞内シグナル伝達については次第に明らかに なってきており, FasやTNFなどの death factorによる 受容体を介したシグナルがカスペースを活性化させ，その 活性化されたカスペースは多様な基質を分解することによ り最終的に細胞死を起こすとされている. 最近, 細胞死の 最終段階で染色体 DNA が caspase-activated deoxyribonuclease (CAD) によって切り出され, この $\mathrm{CAD}$ 活性を 調節している阻害因子 (Inhibitor of CAD; ICAD) が明 らかになった(81).カスペース 3 が ICADを開裂し，そ の $\mathrm{CAD}$ 阻害作用を不活性化させる. CAD の活性化がア ポトーシスに際したヌクレオソーム間 DNA の分解の原因 であり, ICAD はこの過程の阻害因子として働く(82). ICAD はアポトーシスを誘導する適切な刺激によって引き 金が引かれるまでは, $\mathrm{CAD}$ と複合体を形成して $\mathrm{CAD}$ の 活性化を阻害している。しかし, ICAD を過剩に発現させ て $\mathrm{CAD}$ の活性を消失させても, アポトーシスによる細胞 死は認められることから, $\mathrm{CAD}$ のによってアポトーシ スは支配されていないことも分かった(82).これはカスペ ースによって諸種のタンパク質が分解されることによるの かもしれない. 現時点では虚血によってアポトーシスのシ グナルが伝達され, カスペース 1 さらにはカスペース 3 が 活性化されて, カスペース 3 が通常は CADに結合してい る ICAD を分解させて CAD を活性化させていることが考 えられる.このように, CAD および ICAD はアポトーシ ス発現機序の最終段階において重要な役割を演じている可 能性が考えられることから, 今後虚血後の神経細胞障害の 機序に抒けるこれら CAD および ICAD の変化・役割につ いて検討することは大変興味深い点であり, さらにこれら を調節できる特異的な薬物が見い出されれば脳卒中の治療 に寄与できるのかもしれない. 


\section{8. アポトーシス阻害タンパク質（IAP）ファミリー}

アポトーシス阻害タンパク質 (inhibitor of apoptosis protein；IAP）はバキュロウイルスにおいて発見され，シ ヨウジョウバエやヒトにもホモログが存在している。 ヒト の IAP であるXIAP，c-IAP1，c-IAP2 はプロカスペース 9, 活性化型カスペース 3 , 活性化型カスペース 7 および活性 化型カスペース 9 に直接結合して，その活性あるいは活性
化を抑制する(83)．IAP ファミリーのメンバーであるニ ユーロン性アポトーシス阻害タンパク質 (neuronal apoptosis inhibitory protein: NAIP) は，ラット全脳虚血後の 海馬において上昇することが見い出され，NAIPを過剩発 現するためにアデノウイルスベクターを投与すると脳虚血 後の神経細胞障害は軽減された (84)。IAPの欠損や過剩 発現と脳虚血後神経細胞障害の関与ならびにIAP とカス ペースとの関係については今後明らかにされるべき点であ

\section{Ischemia}

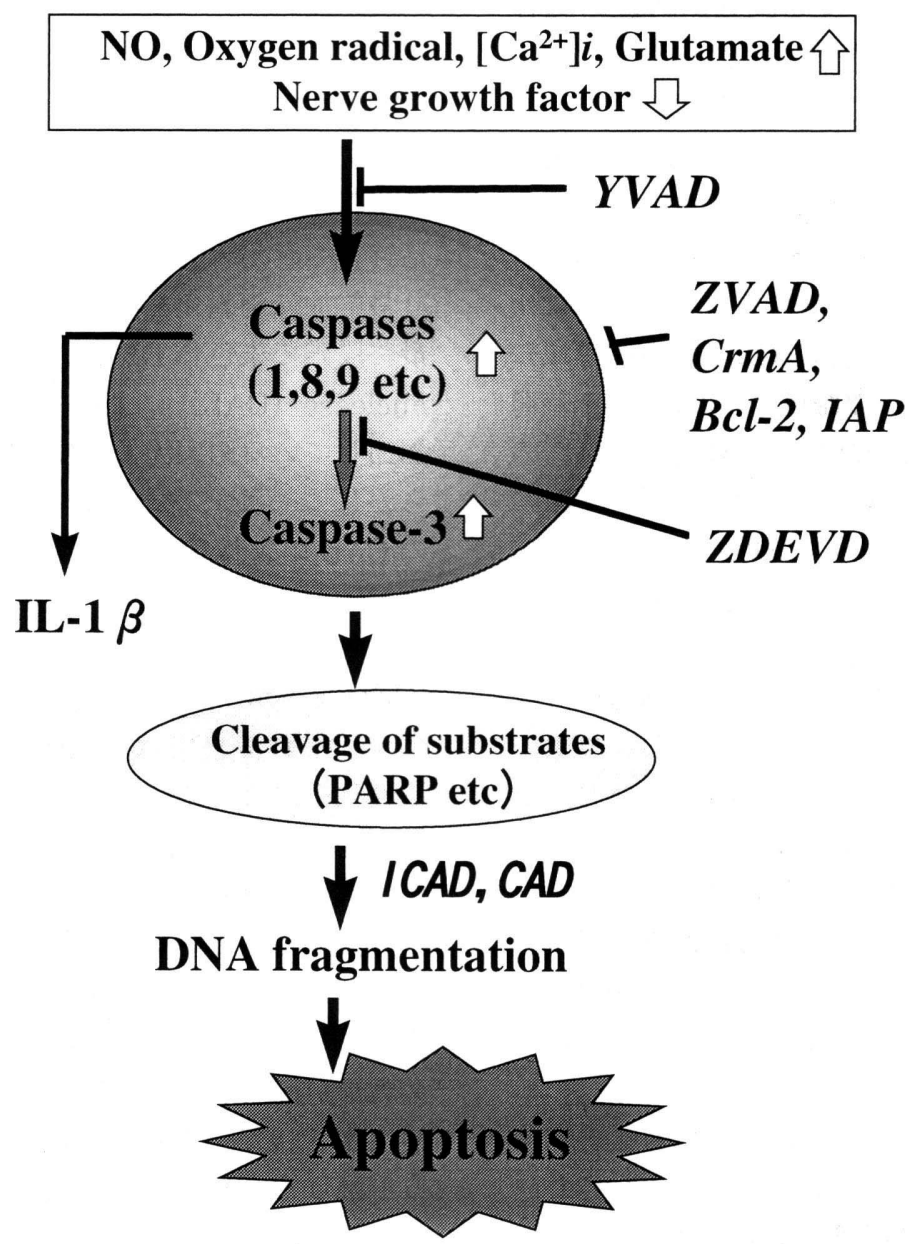

Fig. 5 Speculative model of neuronal cell death mediated by the caspase family after ischemia. A variety of physiological and pathological stimuli can activate signal-transduction pathways that result in the sequential proteolytic activation of caspase family members. The activation of caspases can be inhibited by several molecules, including the Bcl-2, IAP (inhibitor of apoptosis protein), NAIP (neuronal apoptosis inhibitory protein), peptide aldehydes and crmA that target the active-site cysteine of caspase family members. Once activated, caspase-1 (ICE) protease can activate other caspase family members and hydrolyze a discrete set of cellular targets. PARP was recognized as a substrate of activated caspase-3. Cleaved PARP appears to facilitate apoptosis, possibly by interrupting DNA binding and repair at an earlier step than intranucleosomal DNA fragmentation. 
ろう.

\section{9. おわりに}

脳神経細胞は虚血に陥ってから死に至るまでに，ネクロ ーシスかアポトーシスの何れかの過程を辿ることが考えら れる．それは虚血の程度すなわち細胞内の $\mathrm{Ca}^{2+}$ 濃度のレ ベルおよびATP レベル等によって決定される．アポトー シスのシグナルを受けた神経細胞が死に至るまでの過程を 模式的に図 5 に示す。アポトーシスによる細胞死にはカス ペースファミリー, Bcl-2 ファミリーおよび p53 等が関与 しており，カスペースファミリーの中ではとくにカスペー ス 1 およびカスペース 3 の役割が注目されている(89). 脳 虚血後に認められるカスペースの活性化をぺプチド性阻害 薬を用いて抑制することによって, 脳虚血後神経細胞障害 が軽減されることが実験的に証明された。またカスペース 阻害薬の虚血再開通直後の投与は細胞死を軽減することか ら，臨床においてはt-PA (recombinant tissue plasminogen activator）を投与して塞栓を溶解させ血流を再開通 させる際に，カスペース阻害薬を投与することによって再 開通後の障害を防ぐ可能性が考えられる。また，これらカ スペース阻害薬とラジカルスカベンジャーあるいは神経成 長因子などとの併用投与も臨床的効果が期待できる.ささら に脳虚血以外の疾患, たとえば筋萎縮性側索硬化症 (amyotrophic lateral sclerosis: ALS) やアルツハイマー 病においてもそれぞれこれらカスペースが重要な役割を果 たしていることが実験的に証明された $(85,86)$ ことからも， 血液脳関門，神経細胞やグリア細胞内を容易に通過できる カスペース阻害薬が開発されれば，脳卒中のみならず脳損 傷, 脊髄損傷, アルッハイマー病などの幅広い病態の治療 に有用であることが考えられる．今後アポトーシスを制御 する分子機構あるいはアポトーシスにおけるカスペースの 役割がさらに解明されれば，アポトーシスの制御の乱れに 関連したヒト疾患で治療の標的になるものが明らかになり， 抗アポトーシス薬としてのカスペース阻害薬の誕生も夢で はないのかもしれない.

謝辞：本稿の実験結果は, Michael A Moskowitz 教授 (Harvard Medical School, Massachusetts General Hospital, Stroke and Neurovascular Lab.), Junying Yuan 助教授 (Harvard Medical School, Department of Cell Biology), Robert M Friedlander 博士 (Harvard Medical School, Massachusetts General Hospital, Department of Surgery）ならびに教室各員との共同研究により得られ たものであり，ここに感謝の意を表します．また，本総説 を作製するにあたり有益なご指導ならびにご助言を頂きま した三浦正幸先生（大阪大学医学部バイオメディカル教育 研究センター神経機能解剖学) ならびに名村尚武先生（国
立循環器病センター）に感謝致します。また本研究を行う 機会ならびにご支援を頂きました小暮久也先生（長生会脳 機能検診センター), 鐘紡株式会社薬品研究所 中川寛博 士，洲加本孝幸博士をはじめ研究所の方々に深い感謝を表 します。

\section{文献}

1) Kerr JFR, Wyllie AH and Currie AR: Apoptosis: A basic biological phenomenon with wide-ranging implications in tissue kinetics. Br J Cancer 26, 239257 (1972)

2) Thompson CB: Apoptosis in the pathogenesis and treatment of disease. Science 267, 1456-1462 (1995)

3) Shimizu S, Eguchi Y, Kamiike W, Matsuda H and Tsujimoto Y: Bcl-2 expression prevents activation of the ICE protease cascade. Oncogene 12, 22512257 (1996)

4) Choi DW: Ischemia-induced neuronal apoptosis. Curr Opin Neurobiol 8, 667-672 (1996)

5) Kroemer G, Petit PX, Zamzami N, Vayssiere J-L and Mignotte B: The biochemistry of programmed cell death. FASEB J 9, 1277-1287 (1995)

6) Steller H: Mechanisms and genes of cellular suicide. Science 267, 1445-1456 (1995)

7) Duke RC, Ojcius DM and Young JD-E: Cell suicide in health and disease. Sci Am 12, 48-55 (1996)

8) Mundle SD, Gregory SA, Preisler HD and Raza A: Enzymatic programming of apoptotic cell death. Pathobiology 64, 161-170 (1996)

9) Heron A, Pollard H, Dessi F, Lasbennes F, Moreau J, Ben-Ari Y and Charriaut-Marlangue C: Regional variability in DNA fragmentation after global ischemia evidenced by combined histological and electrophoresis observations in the rat brain. $\mathrm{J}$ Neurochem 61, 1973-1976 (1993)

10) Linnik M, Zobrist RH, Pike CJ and Whittemore ER: Evidence supporting a role for programmed cell death in focal cerebral ischemia in rats. Stroke 24, 2002-2009 (1993)

11) MacManus J, Hill I, Huang $Z$, Rasquinha I, Xue D and Buchan A: DNA damage consistent with apoptosis in transient focal ischaemic neocortex. Neuroreport 5, 493-496 (1994)

12) Li Y, Chopp M, Jiang N, Yao F and Zaloga C: Temporal profile of in situ DNA fragmentation after transient middle cerebral artery occlusion in the rat. J Cereb Blood Flow Metab 15, 389-397 (1995)

13) Charriaut-Marlangue C, Margaill I, Represa A, Popovici T, Plotkine M and Ben-Ari Y: Apoptosis and necrosis after reversible focal ischemia: An in situ DNA fragmentation analysis. J Cereb Blood Flow Metab 16, 186-194(1996)

14) Goto K, Ishige A, Sekiguchi K, Iizuka S, Sugimoto A, Yuzurihara M, Aburada M, Hosoya E and Kogure K: Effects of cycloheximide on delayed neuronal death in rat hippocampus. Brain Res 534, 299-302 (1990)

15) Shigeno T, Yamasaki Y, Kato G, Kusaka K, Mima 
T, Takakura K, Graham DI and Furukawa S: Reduction of delayed neuronal death by inhibition of protein synthesis. Neurosci Lett 120, 117-119(1990)

16) Kirino T: Delayed neuronal death in the gerbil hippocampus following ischemia. Brain Res 239, 57-69 (1982)

17) Ferrer I, Tortoise A, Macaya A, Sierra A, Moreno D, Munell F, Blanco R and Squier W: Evidence of nuclear DNA fragmentation following hypoxiaischemia in the infant rat brain, and transient forebrain ischemia in the adult gerbil. Brain $\mathrm{Pa}-$ thol 4, 115-122(1994)

18) Nitatori T, Sato N, Waguri S, Karasawa $Y$, Araki H, Shibanai K, Kominami E and Uchiyama Y: Delayed neuronal death in the CA1 pyramidal cell layer of the gerbil hippocampus following transient ischemia is apoptosis. $\mathrm{J}$ Neurosci 15, 1001-1011 (1995)

19) Petito CK, Torre-Munoz J, Roberts B, Olarte J-P, Nowak TSJr and Pulsinelli WA: DNA fragmentation follows delayed neuronal death in CA1 neurons exposed to transient global ischemia in the rat. J Cereb Blood Flow Metab 17, 967-976(1997)

20) Sei Y, VonLubitz KJ, Basile AS, Barner MM, Lin RCS, Skolnick P and Fossom LH: Internucleosomal DNA fragmentation in gerbil hippocampus following forebrain ischemia. Neurosci Lett 171, 179-182 (1994)

21) Du C, Hu R, Csernansky CA, Hsu CY and Choi D: Very delayed infarction after mild focal cerebral ischemia: a role for apoptosis? J Cereb Blood Flow Metab 16, 195-201 (1996)

22) Endres M, Namura S, Shimizu-Sasamata M, Waeber C, Zhang L, Gomez-Isla T, Hyman BT and Moskowitz MA: Attenuation of delayed neuronal death after mild focal ischemia in mice by inhibition of the caspase family. J Cereb Blood Flow Metab 18, 238-247 (1998)

23) Choi DW: Ischemia-induced neuronal apoptosis. Curr Opin Neurobiol 6, 667-672(1996)

24) Chopp $\mathrm{M}$ and $\mathrm{Li} \mathrm{Y}$ : Apoptosis in focal cerebral ischemia. Acta Neurochir (Wien) 66, 21-26 (1996)

25) MacManus JP and Linnik M: Gene expression induced by cerebral ischemia: An apoptotic perspective. J Cereb Blood Flow Metab 17, 815-832(1997)

26) Hengartner MO and Horvitz HR: C. elegance cell survival gene ced-9 encodes a functional homolog of the mammalian proto-oncogene bcl-2. Cell $\mathbf{7 6}$, 665-676 (1994)

27) Yuan J, Shaham S, Ledoux S, Ellis HM and Horvitz HR: The C. elegans cell death gene ced-3 encodes a protein similar to mammalian interleukin-1b-converting enzyme. Cell 75, 641-652 (1993)

28) Nicholson DW: ICE/CED3-like proteases as therapeutic targets for the control of inappropriate apoptosis. Nature Biotech 14, 297-301 (1996)

29) Schwartz LM and Milligan CE: Cold thoughts of death: the role of ICE proteases in neuronal cell death. Trends Neurosci 19, 555-562(1996)

30) Kuida K, Lippke JA, Ku G, Harding MW, Livingston DJ, Su MS-S and Flavell RA: Altered cytokine export and apoptosis in mice deficient in interleukin 1- $\beta$ converting enzyme. Science 267, 20002002 (1995)

31) Li P, Allen H, Banerjee S, Frankline S, Herzog L, Johnston C, McDowell J, Paskind M, Rodman L, Salfeld J, et al: Mice deficient in IL-1b-converting enzyme are defective in production of mature IL-b and resistant to endotoxic shock. Cell 80, 401-411 (1995)

32) Gagliardini V, Fernandez P-A, Lee RKK, Drexler HCA, Rotello RJ, Fishman MC and Yuan J: Prevention of vertebrate neuronal death by the crmA gene. Science 263, 826-828(1994)

33) Bump NJ, Hackett M, Hugunin M, Seshagiri S, Brady K, Chen P, Ferenz C, Franklin S, Ghayur T, $\mathrm{Li}$ P, et al: Inhibition of ICE family proteases by baculovirus antiapoptotic protein p35. Science 269, 1885-1888 (1995)

34) Milligan CE, Prevette D, Yaginuma H, Homma S, Cardwell C, Fritz LC, Tomaselli KJ, Oppenheim RW and Schwarz LM: Peptide inhibitors of the ICE protease family arrest programmed cell death of motoneurons in vivo and in vitro. Neuron $\mathbf{1 5}$, 385-393 (1995)

35) Martin SJ and Green DR: Protease activation during apoptosis: Death by a thousand cuts? Cell 82, 349-352(1995)

36) Nagata S: Apoptosis by death factor. Cell 88, 355365 (1997)

37) Asahi M, Hoshimaru M, Uemura Y, Tokime T, Kojima M, Ohtsuka T, Matsuura N, Aoki T, Shibahara $\mathrm{K}$ and Kikuchi $\mathrm{H}$ : Expression of interleukin-1b converting enzyme gene family and bcl-2 gene family in the rat brain following permanent occlusion of the middle cerebral artery. J Cereb Blood Flow Metab 17, 11-18(1997)

38) Hara H, Friedlander RM, Gagliardini V, Ayata C, Fink K, Huan Z, Shimizu-Sasamata M, Yuan J and Moskowitz MA: Inhibition of interleukin $1 \mathrm{~b}$ converting enzyme family proteases reduces ischemic and excitotoxic neuronal damage. Proc Natl Acad Sci USA 94, 2007-2012(1997)

39) Namura S, Zhu J, Fink K, Endres M, Srinivasan A, Tomaselli KJ, Yuan J and Moskowitz MA: Activation and cleavage of caspase-3 in apoptosis induced by experimental cerebral ischemia. J Neurosci 15, 3659-3668 (1998)

40) Chen J, Nagayama T, Jin K, Stetler RA, Zhu RL, Graham SH and Simon RP: Induction of caspase-3like protease may mediate delayed neuronal death in the hippocampus after transient cerebral ischemia. J Neurosci 18, 4914-4928(1998)

41) Ni B, Wu X, Su Y, Stephenson D, Smalstig EB, Clemens J and Paul SM: Transient global forebrain ischemia induces a prolonged expression of the caspase- 3 mRNA in rat hippocampal CA1 pyramidal neurons. J Cereb Blood Flow Metab 18, 248-256 (1988)

42) Gillardon F, Bottiger B, Schmitz B, Zimmermann $\mathrm{M}$ and Hossmann K-A: Activation of CPP-32 protease in hippocampal neurons following ischemia and epilepsy. Mol Brain Res 50, 16-22 (1977) 
43) Kinoshita M, Tomimoto H, Kinoshita A, Kumar S and Noda M: Up-regulation of the Nedd2 gene encoding an ICE/Ced-3-like cysteine protease in the gerbil brain after transient global ischemia. J Cereb Blood Flow Metab 17, 507-514(1997)

44) Honkaniemi J, Massa SM, Breckinridge M and Sharp FR: Global ischemia induces apoptosisassociated genes in hippocampus. Mol Brain Res 42, 79-88 (1996)

45) Bhat RV, DiRocco R, Marcy VR, Flood DG, Zhu Y, Dobrzanski P, Siman R, Scott R, Contreras PC and Miller M: Increased expression of IL-b converting enzyme in hippocampus after ischemia: selective locarization in microglia. J Neurosci 16, 4146-4154 (1996)

46) Yakovlev AG, Knoblach SM, Fan L, Fox GB, Goodnight R and Faden AI: Activation of CPP32like caspases contributes to neuronal apoptosis and neurological dysfunction after traumatic brain injury. J Neurosci 17, 7415-7424(1997)

47) Hayashi T, Sakurai M, Abe K, Sadahiro M, Tabayashi K and Itoyama Y: Apoptosis of motor neurons with induction of caspases in the spinal cord after ischemia. Stroke 29, 1007-1013 (1998)

48) Friedlander RM, Gagliardini V, Hara H, Fink KB, Li W, MacDonald G, Fishman MC, Greenberg AH, Moskowitz MA and Yuan J: Expression of a dominant negative mutant of interleukin-1b converting enzyme in transgenic mice prevents neuronal cell death induced by trophic factor withdrawal and ischemic brain injury. J Exp Med 185, 933-940 (1997)

49) Hara H, Fink K, Endres M, Friedlander RM, Gagliardini V, Yuan J and Moskowitz MA: Attenuation of transgenic focal cerebral ischemic injury in transgenic mice expressing a mutant ICE inhibitory protein. J Cereb Blood Flow Metab 17, 370-375 (1997)

50) Schielke GP, Yang G-Y, Shivers BD and Betz AL: Reduced ischemic brain injury in interleukin-1b converting enzyme-deficient mice. J Cereb Blood Flow Metab 18, 180-185(1998)

51) Bergeron L, Perez GI, Macdonald G, Shi L, Sun Y, Jurisicova A, Vermuza S, Latham KE, Flaws JA, Salter JCM, et al: Defects in regulation of apoptosis in caspase-2-deficient mice. Genes Dev 12, 13041314 (1998)

52) Loddick SA, MacKenzie A and Rothwell NJ: An ICE inhibitor, z-VAD-DCB, attenuates ischaemic brain damage in the rat. Neuroreport 7, 1465-1468 (1996)

53) Van Noorden CJF, Smith RE and Rasnick D: Cysteine proteinase activity in arthritic rat knee joints and the effects of a selective systemic inhibitor, ZPhe-AlaCH2F. J Rheumatol 15, 1525-1535(1988)

54) Esser RE, Watts LM, Angelo RA, Thornburg LP, Prior JJ and Paler JT: The effects of fluoromethyl ketone inhibitors of cathepsin $B$ on adjuvant induced arthritis. J Rheumatol 20, 1176-1183(1993)

55) Relton $\mathrm{J}$ and Rothwell N: Interleukin receptor antagonist inhibits neuronal damage induced by cerebral ischaemia or NMDA-receptor activation in the rat. Brain Res Bull 585, 135-141 (1992)

56) Rothwell $\mathrm{N}$ and Relton J: Involvement of cytokines in acute neurodegeneration in the CNS. Neurosci Biobehav Rev 17, 217-227 (1993)

57) Endres M, Wang Z-Q, Namura S, Waeber C and Moskowitz MA: Ischemic brain injury mediated by the activation of poly (ADP-ribose) polymerase. J Cereb Blood Flow Metab 17, 1143-1151(1997)

58) Eliasson MJL, Sammpei K, Mandir AS, Hurn PD, Traystman RJ, Bao J, Pieper A, Wang Z-Q, Dawson TM, Snyder SH et al: Poly (ADP-ribose) polymerase gene disruption renders mice resistant to cerebral ischemia. Nature Med 3, 1089-1095(1997)

59) Liu X, Zou H, Slaughter C and Wang X: DFF, a heterodimeric protein that functions downstream of caspase-3 to trigger DNA fragmentation during apoptosis. Cell 89, 175-184(1997)

60) Wang Z-Q, Auer B, Stingl L, Berghmmer H, Haidacher D, Schweiger $M$ and Wagner EF: Mice lacking ADPRT and poly (ADP-ribosyl)ation develop normally but are susceptible to skin disease. Genes Dev 9, 509-520 (1995)

61) Tsujimoto Y, Finger LR, Yunis J, Nowell PC and Croce CM: Cloning of the chromosome breakpoint of neoplastic B cells with the $\mathrm{t}(14 ; 18)$ chromosome translocation. Science 226, 1097-1099 (1984)

62) Chinnaiyan AM, Orth K, O'Rouke K, Duan H, Poirier GG and Dixit VM: Molecular ordering of the cell death pathway; Bcl-2 and Bcl-XL function upstream of the Ced-3-like apoptotic proteases. J Biol Chem 271, 4573-4576 (1996)

63) Liu X, Kim CN, Yang J, Jemmerson R and Wang $\mathrm{X}$ : Induction of apoptotic program in cell-free extracts; Requirement for dATP and cytochrome c. Cell 86, 147-157 (1996)

64) Yang J, Liu X, Bhalla K, Kim CN, Ibrado AM, Cai J, Peng TI, Jones DP and Wang X: Prevention of apoptosis by Bcl-2: Release of cytochrome c from mitochondria blocked. Science 275, 1129-1132 (1997)

65) Kluck RM, Bossy-Wetzel E, Green DR and Newmeyer DD: The release of cytochrome $\mathrm{c}$ from mitochondria; A primary site for Bcl-2 regulation of apoptosis. Science 275, 1132-1136 (1997)

66) Susin SA, Zamzami N, Castedo M, Hirsch T, Marchetti P, Macho A, Daugas E, Geuskens M and Kroemer G: Bcl-2 inhibits the mitochondrial release of an apoptogenic protease. J Exp Med 184, 1331-1341 (1996)

67) Reed JC: Double identity for proteins of the Bcl-2 family. Nature 384, 773-776(1997)

68) Kroemer G: The proto-oncogene Bcl-2 and its role in regulating apoptosis. Nature Med 3, 614-620 (1997)

69) Chen J, Graham SH, Chan PH, Lan J, Zhou RL and Simon RP: bcl-2 is expressed in neurons that survive focal ischemia in the rat. Neuroreport 6 , 394-398 (1995)

70) Chen J, Graham SH, Nakayama M, Zhu RL, Jin K, Stetler RA and Simon RP: Apoptosis repressor genes bcl-2 and bcl-x-long are expressed in the rat brain following global ischemia. J Cereb Blood Flow Metab 17, 2-10(1997) 
71) Chen J, Zhu RL, Nakayama M, Kawaguchi K, Jin K, Stetler RA, Simon RP and Graham SH: Expression of the apoptosis-effector gene, Bax, is upregulated in vulnerable hippocampal CA1 neurons following global ischemia. J Neurochem 67, 64-71 (1996)

72) Martinou J-C, Dubois-Dauphin M, Staple JK, Rodriguez I, Frankowski H, Missotten M, Albertini P, Talabot D, Catssicas S, Pietra C, et al: Overexpression of BCL-2 in transgenic mice protects neurons from naturally occurring cell death and experimental ischemia. Neuron 13, 1017-1030 (1994)

73) Linnik MD, Zahos P, Geschwind MD and Federoff HJ: Expression of bcl-2 from a defective herpes simplex virus-1 vector limits neuronal death in focal cerebral ischemia. Stroke 26, 1670-1675 (1995)

74) Lawrence MS, Ho DY, Sun GH, Steinberg GK and Sapolsky RM: Overexpression of Bcl-s with herpes simplex virus vectors protects CNS neurons against neurological insults in vitro and in vivo. $J$ Neurosci 16, 486-496 (1996)

75) Lawrence MS, McLaughlin JR, Sun G-H, Ho DY, McIntosh L, Kunis DM, Sapolsky RM and Steinberg GK: Herpes simplex viral vectors expressing bcl-2 are neuroprotective when delivered after a stroke. J Cereb Blood Flow Metab 17, 740-744 (1997)

76) Liebermann DA, Hoffman B and Steinman RA: Molecular controls of growth arrest and apoptosis: P53-dependent and independent pathways. Oncogene 11, 199 (1995)

77) Morrison RS, Wenzel HJ, Kinoshita Y, Robbins CA, Donehower LA and Schwartzkroin PA: Loss of the p53 tumor suppressor gene protects neurons from kainate-induced cell death. J Neurosci 15, 13371345 (1996)

78) Crumrine RC, Thomas $\mathrm{AL}$ and Morgan PF: Attenuation of p53 expression protects against focal ischemic damage in transgenic mice. J Cereb Blood Flow Metab 14, 887-891(1994)

79) Jordan J, Galindo MF, Prehn JHM, Weichselbaum RR, Beckett M, Ghadge GD, Roos RP, Leiden JM and Miller RJ: p53 expression induces apoptosis in hippocampal pyramidal neuron cultures. J Neuro- sci 17, 1397-1405(1996)

80) Xiang H, Hochman DW, Saya H, Fujiwara T, Schwartzkroin PA and Morison RS: Evidence for $p$ 53-mediated modulation of neuronal viability. J Neurosci 16, 6753-6765 (1996)

81) Sakahira H, Enari M and Nagata S: Cleavage of CAD inhibitor in CAD activation and DNA degradation during apoptosis. Nature 391, 96-99 (1998)

82) Enari M, Sakahira H, Yokoyama H, Okawa K, Iwamatsu A and Nagata S: A caspase-activated Dnase that degrades DNA during apoptosis, and its inhibitor ICAD. Nature 391, 43-50 (1998)

83) Li P, Nijhawan D, Budihardjo I, Srinivasula SM, Ahmad M, Alnemri ES and Wang X: Cytochrome c and dATP-dependent formation of apaf-1/caspase-9 complex initiates an apoptotic protease cascade. Cell 91, 479-489 (1997)

84) Xu DG, Crocker SJ, Doucet J-P, ST-Jean M, Tamai K, Hakim AM, Ikeda J-E, Lipton P, Thompson CS, Korneluk RG, et al: Elevation of neuronal expression of NAIP reduces ischemic damage in the rat hippocampus. Nature Med 3, 997-1004(1997)

85) Friedlander RM, Brom RH, Gagliardini V, Wang J and Yuan J: Inhibition of ICE slowa ALS in mice. Nature 388, 31(1997)

86) Kim T-W, Pettingell WH, Jung Y-K, Kovacs DM and Tanzi RE: Alternative cleavage of Alzheimerpresenilins during apoptosis by a caspase- 3 family protease. Science 277, 373-376 (1997)

87) Alnemri ES, Livingston DJ, Nicholson DW, Salvesen G, Thronberry NA, Wong WW and Yuan J: Human ICE/CED-3 protease nomenclature. Cell 87, 171(1996)

88) Pronk GJ, Ramer K, Amiri P and Williams LT: Requirement of an ICE-like protease for induction of apoptosis and ceramide generation by REAPER. Science 271, 808-810 (1996)

89) Barinaga M: Stroke-damaged neurons may commit cellular suicide. Science 281, 1302-1304 (1998)

90) Kuida K, Zheng TS, Na S, Kuan C, Yang D, Karasuyama H, Rakic P and Flavell RA: Decreased apoptosis in the brain and premature lethality in CPP32-deficient mice. Nature 384, 368$372(1996)$ 


\begin{abstract}
Involvement of caspase on apoptosis in ischemia-induced neuronal cell death: Usefulness of caspase inhibitors for stroke therapy. Hideaki HARA (Department of Pharmacology, Pharmaceutical Research Laboratories, Pharmaceuticals R\&D Center, Kanebo, Ltd., Tomobuchi-cho 1-5-90, Miyakojima-ku, Osaka 534-8666, Japan). Folia Pharmacol. Jpn. (Nippon Yakurigaku Zasshi) 113, 97-111 (1999)

This overviews recent understanding of the mechanisms of apoptosis on ischemia-induced neuronal cell death. Apoptosis is a prominent feature of the developing nervous system. Several lines of evidence suggest that apoptosis is also an important mechanism of cell death in adult brain in acute or chronic diseases such as stroke and Alzheimer's disease. In animal models of stroke, markers of apoptosis such as cytoplasmic and nuclear condensation and DNA fragmentation appear in neurons. A variety of physiological and pathological stimuli can activate signal-transduction pathways that result in the sequential proteolytic activation of caspase family members. The activation of caspases can be inhibited by several molecules, including peptide aldehydes (caspase- 1 and/or caspase- 3 inhibitors) and crmA that target the active-site cysteine of caspase family members, Bcl-2, IAP (inhibitor of apoptosis protein) and NAIP (neuronal apoptosis inhibitory protein). Once activated, caspase- 1 protease can activate the caspase family members and hydrolyze a discrete set of cellular targets. Poly (ADP-ribose) polymerase (PARP), which appears to facilitate apoptosis, was recognized as a substrate of activated caspase-3. These results suggest that caspase family, bcl-2 family, IAP family and substrates such PARP contribute to mechanisms of cell death in ischemic brain injury. Inhibition of the caspase family, particularly by non-peptide inhibitors that cross the bloodbrain barrier and easily penetrate neurons and glia, could provide novel treatments for stroke and other forms of brain and spinal cord injury in humans.
\end{abstract}

Keywords: apoptosis; caspase; Bcl-2; ischemia; neuronal damage; PARP 